ROCZNIKI PEDAGOGICZNE

Tom 12(48), numer 4 - 2020

DOI: https://doi.org/10.18290/rped20124-8

LUCYNA MYSZKA-STRYCHALSKA

\title{
AUTONOMIA \\ JAKO ZADANIE (AUTO)EDUKACYJNE MŁODZIEŻY
}

Współczesna wieloznaczna i ambiwalentna rzeczywistość społeczno-kulturowa, poddawana nieustannym fluktuacjom, prowadzi do radykalnych przemian społecznych, które nie pozostają bez znaczenia dla partycypującego w jej przestrzeni człowieka. Obliguje go ona do elastycznego adaptowania się do ciągłych przemian, co znajduje swój wyraz w jego permanentnej autokreacji. Podmiot zobligowany jest do nieustannego dookreślania siebie i udzielania sobie odpowiedzi na pytanie „kim jestem?”. Wymaga to od niego umiejętności tworzenia autorskiej koncepcji życia i przejmowania odpowiedzialności za jej realizację. W spełnieniu tego zadania pomocne okazują się kompetencje związane z samodzielnym uczeniem się, zdobywaniem wiedzy na temat siebie i otoczenia, niezbędnej do analizowania i budowania własnych relacji ze światem. Prawidłowości te zachęcają do podjęcia namysłu nad autonomią i jej znaczeniem dla rozwoju młodego człowieka, który staje przed powinnością skonstruowania tożsamości w okresie dorastania i znalezienia swojego miejsca w świecie. Zagadnienie to zyskuje szczególną wartość poznawczą ze względu na rodzące się refleksje odnoszące się do społecznej pozycji młodzieży (Wrzesień, 2011; Niezgoda, 2014; Szafraniec, 2014), procesu stawania się osobą dorosłą, tj. wyznaczania kierunku własnej aktywności czy też stopnia zaspokajania potrzeb wynikających z jej podmiotowości (Cybal-Michalska, 2006; Oleszkowicz, Senejko 2013).

Młodzież stanowi grupę zróżnicowaną i niejednorodną, o czym świadczą różnorodne sformułowania używane na potrzeby jej dookreślenia, takie jak: „globalny nastolatek”, „młody profesjonalista”, „under class”, „pokolenie L”; odnoszące się do jej partycypacji w świecie nowoczesnych technologii

Dr LuCYNA MysZKA-STRYCHARSKA - Zakład Socjopedagogicznych Problemów Młodzieży, Wydział Studiów Edukacyjnych; adres do korespondencji: ul. Szamarzewskiego 89 (bud. D), 60-568 Poznań; e-mail: lucyna.myszka@amu.edu.pl; ORCID: https://orcid.org/0000-0003-2973-1379. 
„generacja sieci”, „cyfrowi tubylcy”; traktujące o jej aktywności w przestrzeni rynku pracy „pokolenie NEET”, „zmierzający donikąd”, „stracona młodzież”, „trzy razy nic”. Wiele z nich niesie za sobą pejoratywne konotacje dotyczące społecznego wizerunku młodych ludzi. Niewątpliwy wpływ na jakość ich życia mają globalizacja, dynamika i nieprzewidywalność obecnych przemian, zjawiska kulturowe oraz permanentny postęp technologiczny. Wskazane czynniki mogą przyczyniać się zarówno do korzystnego oddziaływania na rozwój ich autonomii, jak i skutecznie ją niszczyć, co niesie ze sobą pewne utrudnienia w rozpoznaniu stanu autonomii współczesnej młodzieży.

Słowo autonomia posiada swój grecki rodowód, powstało bowiem z połączenia dwóch określeń autós - sam, ten właśnie oraz nómos - prawo. Jego semantyka odnosi się do pewnego rodzaju samorządności, możliwości samodzielnego podejmowania decyzji. Niniejszy sposób rozumienia wpisuje się w definicję zamieszczoną w Nowym słowniku wyrazów obcych, zgodnie z którą autonomia jest „prawem do samostanowienia” oraz „całkowitą lub częściową niezależnością polityczną danej zbiorowości, społeczeństwa, instytucji" (Cabała i in., 2003, s. 63-64). Sformułowania te wskazują, że podmiotem autonomii może być jednostka lub grupa. $Z$ kolei treści zawarte w Encyklopedii pedagogicznej sygnalizują, że termin ten posiada zdecydowanie więcej znaczeń. Może być on rozumiany jako: „to, co przypisane, obowiązujące wszystkich”, „samorząd”, ,prawo do samodzielnego rozstrzygania spraw wewnętrznych jakiejś zbiorowości”, „samodzielność, niezależność, odrębność" lub też jako „niezależność od norm etycznych zewnętrznych, innych niż własne sumienie" (Jezierska, 2003, s. 244). Określenia te eksponują aksjonormatywny charakter tej kategorii, co oznacza, że w znaczącym stopniu reguluje ona życie społeczne. W artykule konstrukt ten będzie rozpatrywany w kontekście jednostkowym jako wolność ekspresji siebie (autentyczność) i możliwość realizacji własnych, nieszkodliwych dla otoczenia pragnień poprzez wykorzystanie posiadanych możliwości. Charakteryzuje ona osoby z dominującą orientacją horyzontalnego indywidualizmu, których wysiłki koncentrują się na realizacji samodzielnie wyznaczonych celów i sposobów ich osiągania (Stojanowska, Baj, 2016, s. 26). Dbają zatem o niezależność własnego ,ja”, lecz jednocześnie zachowują szacunek dla odrębności innych ludzi.

Pojęcie autonomii może być stosowane w różnych kontekstach. Jednym z nich jest odniesienie do zadań rozwojowych człowieka. Okres dorastania stanowi moment przejściowy między dzieciństwem a dorosłością, w czasie 
którego jednostka zobowiązana jest do spełnienia określonych wymagań. Piotr Oleś w gronie wyznaczników dojrzałości podmiotu wskazuje m.in. umiejętność samodzielnego wytyczenia kierunku własnego życia i jego celu oraz osiągnięcie niezależności emocjonalnej od rodziców i innych dorosłych, która znajduje swoje odzwierciedlenie w autonomicznym podejmowaniu decyzji i dokonywaniu wyborów (Oleś, 2011). Podobną perspektywę przedstawia Robert Havighurst, poszerzając ją o zadanie uzyskania niezależności ekonomicznej przez młodych ludzi w wyniku przedsięwziętych aktywności zawodowych (Havighurst, 1981). Z kolei Erik H. Erikson analizuje autonomię w kontekście kryzysu rozwojowego mającego miejsce w procesie kształtowania tożsamości. Rozważa on relację między trwałym poczuciem autonomii a doświadczaniem wstydu i zwątpienia. Badacz ten zakładał, że przekonanie o własnej samodzielności podmiotu rozwija się w sytuacjach wskazujących na posiadanie przez niego kontroli w związku z przejawianiem adekwatnego do sytuacji zachowania (Erikson, 1986). W ujęciu rozwojowym autonomia będzie odnosiła się do działania człowieka zgodnie z własnymi normami oraz przekonaniem o posiadanych kompetencjach do podejmowania określonych aktywności związanych z różnymi sferami jego funkcjonowania: psychiczną, prawną, społeczną, ekonomiczną, moralną, emocjonalną, poznawczą, behawioralną (Łapiński, 1988). Dążenie do własnej niezależności przez młodzież jest zjawiskiem zupełnie naturalnym, charakterystycznym dla okresu dorastania. W tym czasie jednostka podejmuje działania ukierunkowane na zintegrowanie dotychczasowej wiedzy o sobie i świecie, które stanowi podwaliny dla krystalizacji jego tożsamości. Zdolność do samodzielnego dookreślania siebie ma niewątpliwe znaczenie podczas poszukiwania odpowiedzi na pytania dotyczące sensu egzystencji, planów życiowych, potrzeb i aspiracji.

Autonomię rozumianą jako bycie sobą, wyrażanie siebie oraz uzewnętrznianie własnych pragnień i możliwości obok homeostazy przejawiającej się $\mathrm{w}$ utrzymywaniu równowagi $\mathrm{w}$ relacjach społecznych i przystosowaniu się do oczekiwań otoczenia uznaje się za istotne standardy rozwojowe człowieka (Niemirowski, 2015, s. 21-22). Niezależność jednostki oddziałuje korzystnie na jakość jej relacji z innymi ludźmi i podejmowane decyzje. Odnosi ona wrażenie współuczestnictwa w wyznaczaniu celów, w obszarze których krystalizuje swoje własne pragnienia. W takim ujęciu autonomia z jednej strony uznawana jest za cel rozwoju podmiotu, z drugiej zaś za jedną z jego podstawowych potrzeb oddziałujących na sposób funkcjonowania. W tym sensie można rozpatrywać ją jako znaczący wymiar podmiotowości 
człowieka, wyrażającej się w jego dążeniu do „ograniczenia zewnętrznej determinacji losów i działań [...] a zwiększenia autodeterminacji" (Reykowski, 1989, s. 202). Stanowi ona bowiem jego atrybut znajdujący swoje odzwierciedlenie w ,autonomicznej mocy sprawczej ukierunkowanej na subiektywnie ważne cele oraz gotowości do ponoszenia odpowiedzialności za wybory i czyny" (Czerepaniak-Walczak, 1999, s. 77). Niniejsza perspektywa wskazuje na warte uwagi konotacje autonomii oraz pokrewnych pojęć, takich jak sprawstwo, emancypacja, odpowiedzialność i wolność, w kontekście których również poszukuje się odniesień do praktyki edukacyjnej ukierunkowanej nie tylko na proces zdobywania wiedzy, lecz również na kształtowanie postawy krytycznej człowieka.

Orientacja na autonomię stanowi także jeden ze wskazywanych typów orientacji zawodowej. Konstrukt ten pojawia się w pracach wielu badaczy kariery, w gronie których warto wskazać Mariana Kloczkowskiego (2005), C. Brooklyna Derra (1988), J.J. Kirka, L.D. Kirk (1995), Henryka Skłodowskiego, Tadeusza Kucharskiego (2000) oraz Edgara Scheina (1993). Zgodnie uznają oni, że osoby ukierunkowane na niezależność w pracy preferują samodzielne podejmowanie decyzji, co przekłada się na zarządzanie własnym rozwojem zawodowym. W sytuacji, w której posiadają pożądaną swobodę działania, wykazują się zwiększoną umiejętnością radzenia sobie w sytuacjach trudnych. W tym kontekście nie sposób pominąć koncepcję kotwic kariery autorstwa E. Scheina. W myśl jej założeń każdy człowiek charakteryzuje się względnie trwałym zorientowaniem na określone potrzeby i wartości w odniesieniu nie tylko do sfery własnego życia zawodowego, ale także pozostałych obszarów aktywności. „Kotwice” pełnią funkcję pewnego rodzaju „przewodnika", który w znacznym stopniu warunkuje to, „do czego” lub/i „ku czemu” dąży jednostka oraz czego oczekuje od własnego życia (Schein, 1993). Niniejsze ukierunkowanie życiowe oddziałuje na percepcję podmiotu, która nie pozostaje bez znaczenia dla przyjmowanych przez niego wartości, potrzeb i poczucia kompetencji w określonych obszarach działania. Można zatem uznać, że określony „przewodnik” stanowi niejako rdzeń tożsamości człowieka oraz wyznacza kierunek rozwoju.

Autonomia jest warunkiem niezbędnym do wystąpienia czterech zasadniczych czynników rozwoju człowieka, takich jak samoświadomość, samopotwierdzenie, samoedukacja, samorefleksyjność. Przedrostek „samo” wskazuje

\footnotetext{
${ }^{1}$ Pojęciem „przewodnika”, w odniesieniu do koncepcji kotwic kariery E. Scheina, w swojej pracy posługuje się A. Cybal-Michalska, stąd też zostało zaczerpnięte niniejsze określenie (Cybal-Michalska, 2013, s. 332).
} 
na podmiotowe wycieniowanie tych procesów - ich dynamikę w znaczącym stopniu warunkuje własna aktywność jednostki. Według Gordona W. Allporta podmiot niezależny będzie charakteryzował się dojrzałą osobowością i poczuciem spójnej tożsamości, która znajduje swój wyraz w realistycznej percepcji siebie, umiejętności osiągania i przeżywania sukcesów oraz w radzeniu sobie z niepowodzeniami (Allport, 1988). W tym kontekście warto nadmienić o koncepcji samodeterminacji Edwarda L. Deciego i Richarda M. Rayana, zgodnie z którą potrzeba autonomii ma kluczowe znaczenie dla kształtowania subiektywnego dobrostanu psychicznego człowieka, stanowiącego podstawę homeostatycznej i spójnej osobowości oraz skutecznego działania (Deci, Rayan, 2000, s. 229). Jednostka autonomiczna będzie zatem charakteryzowała się umiejętnością kierowania własnym zachowaniem i podejmowania decyzji, uwzględniając osobiste potrzeby, jednak wykluczając działanie na szkodę innych ludzi.

W zrozumieniu znaczenia autonomii w okresie dorastania pomocne może okazać się przyjrzenie się antonimom tej kategorii, tj. heteronomii lub też anomii. Heteronomia ma miejsce w sytuacji, w której podmiot poddaje się normom i zasadom ustalonym przez innych ludzi i czyni to ze względu na sankcje, będące konsekwencją ich nieprzestrzegania (Okoń, 2007, s. 134). Perspektywa ta znajduje swoje odzwierciedlenie w psychologicznych teoriach moralności. Jean Piaget drugie stadium rozwoju moralnego określa mianem heteronomii moralnej, w czasie którego dziecko respektuje zewnętrzne wobec niego reguły ze względu na negatywne następstwa niewłaściwego zachowania nakładane na nie przez dorosłych (Trempała, Czyżowska, 2002, s. 114). Jest ono poprzedzone etapem anomii moralnej, czyli stanem braku świadomości moralnej charakterystycznej dla człowieka do drugiego roku życia (tamże, s. 107) ${ }^{2}$. Następstwem obu tych stadiów jest autonomia moralna, w czasie której młody człowiek internalizuje zasady społeczne i na ich podstawie wyznacza wartości, bazujące na indywidualnych standardach normatywnych. Można zatem stwierdzić, że w kontekście rozwoju moralnego przechodzenie jednostki od stanu anomii, przez heteronomię do autonomii jest sytuacją naturalną i pożądaną, wieńczoną osiągnięciem przez nią dojrzałości. Wskazane stadia następują bowiem w niezmiennej

\footnotetext{
${ }^{2}$ Zbliżone ujęcie rozwoju myślenia moralnego można odnaleźć w koncepcji Lawrence Kohlberga. Badacz ten zakładał, że człowiek przechodzi przez sześć stadiów rozwoju moralnego, które można podzielić na trzy podstawowe poziomy: przedkonwencjonalny, konwencjonalny i pokonwencjonalny. Moralność przedkonwencjonalna odpowiada piagetowskiej anomii i heteronomii moralnej (Kohlberg, 1981).
} 
kolejności, a każde z nich toruje drogę następnemu. Ich wystąpienie okazuje się również niezbędne w procesie rozwoju poznawczego, ponieważ oddziałują na kształtowanie różnych sposobów myślenia człowieka, które prowadzą do odmiennych strategii rozwiązywania tych samych problemów (Kohlberg, Mayer, 2000, s. 29).

Anomia może być także rozpatrywana jako pewien rodzaj reakcji jednostki na przyśpieszony proces przemian społecznych i deregulacji systemu wartości, przejawiający się w jej poczuciu zagubienia i braku identyfikacji z istniejącymi normami (Wrzesień, 2017). Jej skutkiem mogą być obniżone aspiracje podmiotu, minimalizacja potrzeb i oczekiwań życiowych. Prawidłowości te są dostrzegalne w różnorodnych koncepcjach odnoszących się do młodzieży. Wśród nich plasuje się psychologia nic nierobienia (psychology of doing nothing), której istota tkwi w dostrzeganiu bezsensowności planowania, jako reakcji na nieciągłość, przemijalność i dyskontynuację znaczeń, której efektem jest obojętność decyzyjna (Anderson, 2003). Z kolei Jeffrey Arnett, autor koncepcji „wschodzącej (wyłaniającej się) dorosłości” (emerging adulthood), zwraca uwagę na rozmywanie granic w procesie tranzycji z okresu dorastania do dorosłości. Traktuje ona o tym, że młodzież w wieku 18-25/29 lat wyróżnia się niestabilną strukturą tożsamości, koncentruje się wyłącznie na sobie i własnych potrzebach oraz eksperymentuje w różnych sferach życia (Arnett, 2000). Efektem tego jest przedłużanie fazy moratorium i odraczaniem momentu podejmowania trwałych zobowiązań, takich jak założenie rodziny czy też opuszczenie domu rodzinnego (tamże; Merino, Gracia, 2006).

Analizy moratorium psychospołecznego dokonywane w pracach Erika $\mathrm{H}$. Eriksona kontynuował James Marcia (1980), który wyodrębnił cztery statusy tożsamości: rozproszony, nadany (przekazany), moratoryjny (odroczony), osiągnięty. Kształtują się one w trakcie dwóch procesów eksploracji, polegającej na poznawaniu otoczenia przez podmiot $\mathrm{w}$ wyniku eksperymentowania $\mathrm{i}$ testowania granic oraz zaangażowania związanego $\mathrm{z}$ odpowiedzialnym realizowaniem zobowiązań będących konsekwencją podjętych decyzji. Współczesne badania bazujące na niniejszej koncepcji dowodzą, że młodzież akademicka charakteryzuje się wysokim natężeniem eksploracji, zaś niskim w przyjmowaniu zobowiązań. W efekcie coraz niższy jej odsetek wyróżnia się tożsamością osiągniętą, podczas gdy wzrasta popularność tożsamości niezróżnicowanej (bez dominującego któregokolwiek z wymiarów tożsamości) (Brzezińska, Piotrowski, 2009). Krystalizacja tożsamości stanowi warunek konieczny niezależnego działania, ponieważ stanowi ona rdzeń odpowiedzialny za podejmowanie samodzielnych wyborów. 
Przytoczone przykłady dowodzą, że edukacyjne oraz wychowawcze zaniedbanie ukierunkowania młodzieży na autonomię może skutkować nie tylko deregulacją tożsamości, brakiem zdolności do stworzenia autodefinicji siebie, biernością funkcjonalną i decyzyjną oraz nieumiejętnością przyjęcia zobowiązań, ale także powstawaniem dewiacji społecznych o charakterze anomicznym (np. niejednoznaczność w postępowaniu, brak poczucia sensu) (Merton, 1982; Sztompka, 2004, s. 275). Niniejsze następstwa zazwyczaj nie zaburzają funkcjonowania systemu społeczno-gospodarczego, ale oddziałują niekorzystnie na jakość egzystencji jednostki. Poziom przejawianej przez nastolatków autonomii zarówno na poziomie emocjonalnym, jak i funkcjonalnym oddziałuje na jakość prezentowanego przez nich przystosowania społecznego. Oznacza to, że warunkuje on rozwój ich kompetencji społecznych oraz akademickich, samoocenę, skłonność do zachowań problemowych oraz nastrojów depresyjnych (Noom i in., 1999). Istotne znaczenie dla kształtowania autonomii młodego człowieka ma postawa rodziców. Elastyczny stosunek wobec potrzeb młodego człowieka, poszanowanie jego samodzielności i pełna akceptacja, sprzyjają przyjmowaniu jego pozytywnej samooceny, która oddziałuje na podejmowane przez niego decyzje i działania (Sabaj-Sidur, 2018, s. 62).

Konglomerat przemian współczesnego świata, niemożliwość przewidywania mających nastąpić stanów rzeczy, przyczynia się do spadku wiary młodzieży we własne szanse na modyfikację własnego otoczenia. Wyniki badań prowadzonych przez Witolda Września wskazują jednoznacznie, iż pokolenie młodych z czasów transformacji ustrojowej przejawiało optymistyczne ustosunkowanie wobec własnych zdolności do kształtowania przyszłości i realizowania zamierzonej ścieżki kariery zawodowej, podczas gdy u kolejnych generacji można zaobserwować tendencję do prezentowania niskiej oceny swojej sposobności do wywierania wpływu na rzeczywistość (Wrzesień, 2011). Młodzi ludzie coraz później osiągają niezależność od rodziców, co w konsekwencji skutkuje także odraczaniem momentu przyjmowania zobowiązań charakterystycznych dla dorosłych (Brzezińska, 2011). Sytuacja stawia autonomię współczesnych nastolatków pod znakiem zapytania oraz wskazuje na pewien związany $\mathrm{z}$ nią paradoks. $Z$ jednej strony znaczący odsetek (powyżej 70\%) młodzieży akademickiej (Cybal-Michalska, 2013, s. 274) i uczęszczającej do szkół ponadpodstawowych (Myszka-Strychalska, 2018, s. 37) deklaruje, że jest ona przekonana o posiadaniu możliwości sprawczych, wyrażających się w zdolności oddziaływania na wydarzenia mające miejsce w życiu, z drugiej zaś strony „wybiórczo” podchodzi do ich wykorzystywania. 
Próby wyjaśnienia tej prawidłowości można dopatrywać się w „paradoksie refleksyjności" Wojciecha Burszty (2004, s. 36). Występuje on zawsze wtedy, gdy jednostka staje przed dylematem dążenia do własnej indywidualności i niezależności a poddaniem się oddziaływaniom instytucjonalizacji na codzienne doświadczenia. Oznacza to, że z jednej strony jednostka chce zachować całkowitą samodzielność, z drugiej zaś przejawia potrzebę zaspokojenia potrzeby przynależności do społeczeństwa. Konsekwencją owego stanu jest kształtowanie tożsamości typu insert - otwartej na nowe przeżycia i wiadomości, które są włączane w jej strukturę, jednak tylko na czas swojej przydatności (Burszta, 2004, s. 37).

Zagrożenia dla rozwoju autonomii młodzieży należy poszukiwać także w samej organizacji procesu edukacji. $Z$ jednej strony wydłużający się czas pobytu $\mathrm{w}$ instytucjach edukacyjnych może być postrzegany jako wydłużenie okresu kontroli młodych ludzi, którzy dążąc do uniknięcia odrzucenia, niejednokrotnie są gotowi do wyrzekania się swojego prawdziwego ,ja" (Norbert, 2008, s. 37-40). Z drugiej zaś strony prawo wolnego wyboru, samosterowność i dialog równouprawnionych stron stanowią jedne z podstawowych postulatów współczesnej edukacji, które mają zostać osiągnięte podczas kształcenia. Wyniki badań uzyskanych przez Elżbietę Stojanowską i Mariusza Baja dowodzą, że doświadczenie autonomii w czasie edukacji stanowi nie tylko warunek krystalizacji zrównoważonej osobowości i poczucia dobrostanu psychicznego, ale także zwiększa szanse jednostki na osiąganie zadowolenia ze studiów (Stojanowska, Baj, 2016). Ponadto osoby ukierunkowane na swój własny rozwój w procesie uczenia się, przejawiające wysoki stopień niezależności, odczuwają większą satysfakcję ze zdobywanej wiedzy oraz wyróżniają się wyższą motywacją (MacDougall, 2008).

Wincenty Okoń wskazuje, że formami aktywności szczególnie sprzyjającymi rozwojowi autonomii młodzieży jest praca pozalekcyjna lub pozaszkolna oraz działalność w różnego rodzaju organizacjach (Okoń, 2007, s. 37). Istotne okazuje się podjęcie namysłu nad tym, jakie działania warto podjąć, by młodzież mogła zaspokajać potrzebę autonomii również podczas edukacji formalnej. Celem dostarczenia jej takich doświadczeń należy zwiększyć szansę na rozwój jej zainteresowań i pasji oraz stwarzać sytuacje pozwalające na utrwalenie poczucia wolności i zachowania własnej odrębności, wyjątkowości. Stają się one kluczowe w kształtowaniu niezależnego „,ja” implikującego odkrywanie i wskazywanie własnych atrybutów, niezbędnych dla procesu dookreślania siebie (Singelis, 1994). Przykładem działań wspierających rozwój autonomii będą przedsięwzięcia wzorujące się na teorii 
samodeterminacji (self determination theory) (Rayan, Deci, 2008). Zgodnie z jej założeniami podmiot samodzielnie decyduje o zadaniach, które będzie wykonywał, oraz wybiera sposób ich realizacji. W wyniku eksploracji samego siebie - własnych doświadczeń i przeżyć - wzmacnia swoją samoświadomość odnośnie tego, co jest dla niego istotne i przynosi mu satysfakcję, co w efekcie zachęca go do podejmowania inicjatyw i odpowiedzialnego kierowania nimi.

Ważne jest określenie konsekwencji włączenia autonomii do grona wartości edukacyjnych oraz uczynienia z niej istotnego czynnika sterującego praktyką edukacyjną. Instytucje kształcenia, funkcjonujące na zasadzie swobody działania w określonym zakresie, sprzyjają powstawaniu autonomicznych cech osobowości człowieka (Aviram, 2000, s. 87-88). Założenie to winno przekładać się na określenie obszarów aktywności pedagogicznej, w których następowałoby rozwijanie ukierunkowania młodzieży na autonomię. Warto jednak zaznaczyć, że sama orientacja na autonomię (cenienie sobie niezależności przez podmiot) nie gwarantuje jej doświadczania, aby tak się stało, należy przebywać $\mathrm{w}$ środowisku pozwalającym na dokonywanie samodzielnych wyborów, szanujących odrębność jednostki. Kreowanie sytuacji ukierunkowanych na samostanowienie młodego człowieka w procesie kształcenia stanowi zadanie, którego nie można pomijać. Autonomia stanowi bowiem podstawowy wymiar godności człowieka, stwarzający podwaliny dla szacunku wobec siebie i innych oraz poczucia obowiązkowości (Kant, 2002, s. 72).

Zbigniew Kwieciński zaznacza, że edukacja stoi przed dylematem wyznaczenia kierunku rozwoju młodego człowieka, który z jednej strony powinien mieć prawo do podejmowania samodzielnych decyzji, jednak z drugiej szkoła zobowiązana jest do wykształcenia u niego umiejętności krytycznego osądu różnych zjawisk na podstawie wartości kulturalnych bez nadużywania swojego autorytetu (Kwieciński, 2012, s. 75). Badacz ten stwierdza, że pomimo tego, iż tak rozumiana autonomia $\mathrm{z}$ demokratycznego punktu widzenia stanowi szczytny cel wychowania, to w obecnym systemie szkolnictwa opartym na założeniach programowych oraz określonej strukturze nie jest on możliwy do realizacji (Kwieciński, 2011, s. 222). W nielicznych placówkach edukacyjnych podejmuje się bowiem próby wcielania postulatów pedagogicznych dotyczących pełnomocności podmiotu i jego osobistej niezależności. Warto wśród nich wskazać szkoły waldorfskie oparte na pedagogice Rudolfa Steinera (1998), koncepcję flexichoolingu Rolanda Meighana (1991) oraz koncepcję edukacji zorientowanej na autonomię (autonomy-oriented education) Ahrona Avirama (1993). Zgodnie akcentują one konieczność 
budowania instytucji kształcenia na podstawie zasady otwartości, która sprzyja przygotowywaniu młodzieży do elastycznego radzenia sobie w warunkach zmiennej rzeczywistości.

Istotnym czynnikiem warunkującym rozwój autonomii młodzieży jest postrzeganie tej grupy społecznej przez pryzmat partnerstwa. Niniejszego postulatu możemy dopatrywać się w słowach Barbary Fatygi, która zauważa, iż „nie należy traktować młodego pokolenia jako osobnej kategorii, dla której trzeba «coś zrobić», lecz należy nastawić się raczej na działania łączące różne grupy pokoleniowe, przede wszystkim dzieci i młodzież oraz ludzi starych. Jest to potrzebne, by zapobiegać zamykaniu się młodych ludzi we własnych wąskich środowiskach" (Fatyga, 2009, s. 42-43). Można z dużym prawdopodobieństwem przewidywać, iż nastolatek traktowany jako uczestnik życia społecznego, nie zaś jako obiekt oddziaływań pedagogicznych, będzie bardziej zmotywowany do podejmowania aktywności, dokonywania wyborów i ponoszenia za nie odpowiedzialności.

Możliwość rzeczywistego uczestnictwa w przestrzeni społecznej, przekonanie o swojej podmiotowości i świadomość posiadanych zasobów to jedne z zasadniczych czynników warunkujących podejmowanie praktyk o charakterze autoedukacyjnym przez młodzież. Jednostka, która ma sposobność do własnej eksploracji, eksperymentowania i partycypowania w różnych perspektywach poznawczych, rozwija swoją inicjatywność i przejmuje odpowiedzialność za kształtowanie siebie (Siadak, 2011). Właściwości te okazują się niezbędne $\mathrm{w}$ procesie refleksyjnego konstruowania tożsamości przez człowieka, która obecnie staje się projektem wymagającym permanentnej autokreacji (Cybal-Michalska, 2006). Autoedukacja rozumiana jako „własna praca jednostki nad urzeczywistnianiem siebie według jakiegoś ideału lub wzoru osobowego" (Jankowski, 2003, s. 232-233) jest możliwa przy zapewnieniu jej odpowiednich warunków do dokonywania samodzielnych wyborów i określania celów oraz posiadaniu przez nią samoświadomości (poczucia sprawstwa) w kwestii refleksyjnej pracy nad sobą. Życie w świecie niepewności jutra, związanej z niepokojem i doświadczaniem ambiwalencji przez podmiot, sprawia że autonomia ukierunkowana na samorealizację, samosterowność i odpowiedzialność za własną przyszłość staje się koniecznością.

Autonomia może stanowić zarówno pochodną zewnętrznych warunków pozwalających człowiekowi na własny wybór (przyzwolenia na realizację autonomii), jak też wynik jego świadomego i intencjonalnego działania. Odnosi się do wielu sfer partycypacji jednostki m.in.: kształtowania tożsamości, aktywności zawodowej, radzenia sobie z trudnościami, kształtowania 
systemu wartości czy wykorzystania możliwości rozwoju. Będzie zatem przejawiać się $\mathrm{w}$ niezależnym od innych sposobie zachowywania się podmiotu, samodzielności emocjonalnej i poznawczej, znajdującej swoje odzwierciedlenie w jego własnych ocenach i myślach. Tak rozumiana autonomia nie jest cechą, którą można obdarzyć człowieka, lecz pewnym zadaniem, którego realizacji dopatrujemy się w procesie edukacyjnym stwarzającym okazje do różnego rodzaju interakcji ukierunkowanych na kształtowanie niezależnej jednostki. Podmiotowa sprawczość oraz umiejętność radzenia sobie $\mathrm{w}$ warunkach dynamicznej zmiany determinują aktywną samorealizację nastolatków. Dlatego też problematyka autonomii młodego człowieka, będąca czynnikiem konstruktywnym dla utrzymania ciągłości jego własnego „ja” w warunkach zmiany społecznej, lokuje się wśród najważniejszych zagadnień poddawanych refleksji pedagogicznej.

\section{BIBLIOGRAFIA}

Allport, G.W. (1988). Osobowość i religia, tłum. H. Bartoszewicz. Warszawa: PAX.

Anderson, C.J. (2003). The psychology of doing nothing: Forms of decision avoidance from reason and emotion. Psychological Bulletin, 129, 139-167.

ARnETT, J.J. (2000). Emerging adulthood: A theory of development from the late teens through the twenties. American Psychologist, 55, 469-480.

Aviram, A. (1993). Personal Autonomy and the Flexible School. International Review of Education, 39(5), 419-433.

Aviram, A. (2000). Autonomia i zaangażowanie: dopełniające się ideały, tłum. G.T. Wysocka. Acta Universitatis Nicolai Copernici. Nauki Humanistyczno-Społeczne. Socjologia Wychowania, 14(339), 79-94.

Brzezińska, A.I., Kaczan, R., Piotrowski, K., RęKosiewicz, M. (2011). Odroczona dorosłość: fakt czy artefakt? Nauka, 4, 67-107.

Brzezińska, A.I., Piotrowski, K. (2009). Diagnoza statusów tożsamości w okresie adolescencji, wyłaniającej się dorosłości i wczesnej dorosłości za pomocą Skali Wymiarów Rozwoju Tożsamości (DIDS). Studia Psychologiczne, 47(3), 93-109.

Burszta, W. (2004). Tożsamość narracyjna w dobie ekranu. W: W. Bolecki, R. NyCz (red.), Narracje i tożsamość, t. 1 (s. 26-37). Warszawa: Instytut Badań Literackich.

CabaŁA, A., Latoń, D., LAtusek, A., SobiŁo, B. (2003). Nowy słownik wyrazów obcych. Kraków: Zielona Sowa.

CyBAL-MichalsKA, A. (2006). Rozwój autentycznego „Ja” - elastyczne i otwarte formy jednostkowej identyfikacji. W: A. CyBAL-MiCHALSKA (red.), Jednostka, społeczeństwo i edukacja w globalnym świecie (s. 23-35). Leszno-Poznań: Wyższa Szkoła Humanistyczna.

Cybal-Michalska, A. (2006). Tożsamość młodzieży w perspektywie globalnego świata. Studium socjopedagogiczne. Poznań: Wydawnictwo Naukowe UAM. 
CyBal-MichalskA, A. (2013). Młodzież akademicka a kariera zawodowa. Kraków: Oficyna Wydawnicza Impuls.

CzerpaniaK-WAlczaK, M. (1999). Podmiotowość jako kategoria pedagogiczna u edukacyjna. W: E. Kubiak-Szymborska (red.), Podmiotowość w wychowaniu. Między ideq a realnościq (s. 76-90). Bydgoszcz: Wers.

DeCI, E.L., RYAN, R.M. (2000). The „what” and „why” of goal pursuits: Human needs and the self-determination of behavior. Psychological Inquiry, 11(4), 227-268.

DERR, C.B. (1988). Managing the new careerist. The diverse career success orientation of today's workers. San Francisco, Jossey-Bass.

ERIKSON, E.H. (1986). Identity: Youth and Crisis. New York-London: W.W. Norton.

FATYGA, B. (2009). Diagnoza społeczna młodzieży: skład społeczny i style życia. W: G. ZIELIŃSKA (red.), Polityka młodzieżowa (s. 11-45). Warszawa: Biuro Analiz Sejmowych Kancelarii Sejmu.

HAVighurst, R.J. (1981). Developmental tasks and education. New York: Longman.

JANKowski, D. (2003). Autoedukacja. W: T. PILCH (red.), Encyklopedia pedagogiczna XXI wie$k u$, t. 1 (s. 232-239). Warszawa: Wydawnictwo Akademickie „Żak”.

JeZIERSKA, B. (2003). Autonomia. W: T. Pilch (red.), Encyklopedia pedagogiczna XXI wieku, t. 1 (s. 244-246). Warszawa: Wydawnictwo Akademickie „Żak”.

KAnt, I. (2002). Uzasadnienie metafizyki moralności, thum. M. Wartenberg. Warszawa: Altaya.

KIRK, J.J., KIRK, L.D. (1995). Training games for career development quarterly. New York: Wiley.

Kloczkowski, M. (2005). Orientacje społeczne i zawodowe kadry Wojska Polskiego w okresie transformacji systemowej. Wrocław: Wydawnictwo Uniwersytetu Wrocławskiego.

Kohlberg, L. (1981). Essays on moral development, t. 1: The Philosophy of Moral Development: Moral Stages and Idea of Justice. New York: Harper and Row.

Kohlberg, L., Mayer, R. (2000). Rozwój jako cel wychowania, thum. P. Kwieciński, A. Nalaskowski. W: Z. KWIECIŃSKI (red.), Alternatywy myślenia o/dla edukacji (s. 75-79). Warszawa: IBE.

KwIECIŃSKI, Z. (2011). Cztery i pót. Preliminaria. Liminaria. Varia. Wrocław: Wydawnictwo Naukowe Dolnośląskiej Szkoły Wyższej.

KwIEcińSKI, Z. (2012). Pedagogie postu. Preteksty. Konteksty. Podteksty. Kraków: Oficyna Wydawnicza „Impuls”.

Lumpkin, G.T., Dess, G.G. (1996). Clarifying the Entrepreneurial Orientation Construct and Linking It to Performance. Academy of Management Review, 21(1), 135-172.

ŁAPIŃSKI, B. (1988). Rola rodziny w osiąganiu autonomii przez dziecko w okresie dorastania. Psychologia wychowawcza, 31(5), 499-507.

MacDougall, M. (2008). Ten tips for promoting autonomous learning and effective engagement in the teaching of statistic to undergraduate medical students involved in short-term research projects. Journal of Applied Quantitative Methods, 3(3), 223-240.

MARCIA, J.E. (1980). Identity in adolescence. W: J. ADELSON (red.), Handbook of adolescent psychology (s. 159-187). New York: John Wiley and Sons.

Meighan, R. (1991). Edukacja elastyczna. Jutro twojego dziecka decyduje sie dzisiaj, thum. A. Nalaskowski. Toruń: Stowarzyszenie „Nasza Szkoła”. 
Merino, R., Gracia, M. (2006). Emancipation enlargement and the acquisition of autonomy by young people in Catalonia. Young, 14(1), 33-47.

Merton, R.K. (1982). Teoria socjologiczna i struktura społeczna, thum. E. Morawska, J. Wertenstein-Żuławski. Warszawa: PWN.

MYSZKA-STRYCHALSKA, L. (2018). Orientacje prorozwojowe współczesnej młodzieży. W: A. CYBal-Michalska, B. Kanclerz, L. Myszka-Strychalska, P. Peret-Drążewska (red.), Młodzież we wspótczesnej rzeczywistości społeczno-kulturowej (s. 23-51). Poznań: Wydawnictwo Naukowe UAM.

Niemirowski, T. (2015). Pojęcie rozwoju w psychologii rozwojowej. Horyzonty Psychologii, 5(1), 13-28.

NiEzGoda, M. (2014). Młodzież. Kłopotliwa kategoria socjologiczna. Jagiellońskie Studia Socjologiczne, 1, 13-34.

Noom, M.J., Deković, M., Meeus, W.H.J. (1999). Autonomy, attachment and psychosocial adjustment during adolescence: a double-edged sword? Journal of Adolescence, 22(6), 771-783.

Norbert, E. (2008). Społeczeństwo jednostek, tłum. J. Stawiński. Warszawa: Wydawnictwo Naukowe PWN.

OкоŃ, W. (2007). Nowy stownik wyrazów pedagogicznych. Warszawa: Wydawnictwo Akademickie „Żak”.

Oleszkowicz, A., SEneJKo, A. (2013). Psychologia dorastania. Zmiany rozwojowe $w$ dobie globalizacji. Warszawa, Wydawnictwo Naukowe PWN.

OleŚ, P. (2011). Psychologia człowieka dorosłego. Warszawa, Wydawnictwo Naukowe PWN.

ReYkowski, J. (1989). Podmiotowość - szkic problematyki. W: P. BuczKOwski, R. Cichocki (red.), Podmiotowość: możliwość, rzeczywistość, konieczność (s. 199-212). Poznań: Wydawnictwo Nakom.

RyAn, R.M., DECI, E.L. (2008). A self-determination theory approach to psychotherapy: The motivational basis for effective change. Canadian Psychology, 49(3), 186-193.

SABAJ-SidUR, M. (2018). Nadzieja na sukces i samoocena młodzieży a spostrzeganie postaw rodziców. Lublin: Wydawnictwo KUL.

ScheIn, E.H. (1993). Career anchors. Discovering your real values. San Diego: Pfeiffer.

SIADAK, G. (2011). Autoedukacja wyzwaniem XXI wieku - rola uczelni wyższej w procesie samokształcenia studentów. Forum Dydaktyczne, 7-8, 119-127.

Singelis, T.M. (1994). The measurement of independent and interdependent self-construals. Personality and Social Psychology Bulletin, 20(5), 580-591.

SKŁOdOWSKI, H., KUCHARSKI, T. (2000). Kwestionariusze wykorzystywane w poradnictwie zawodowym. Łódź-Toruń: H. Skłodowski, T. Kucharski.

STEINER, R. (1998). O wychowaniu dziecka z punktu widzenia wiedzy duchowej, thum. E. Łyczewska. Łódź: Wydawnictwo Wyższej Szkoły Humanistyczno-Ekonomicznej.

Stojanowska, E., BAJ, M. (2016). Zadowolenie ze studiów u osób z różnym nasileniem orientacji społecznych Ja. Rola doświadczenia zdobywanego na studiach. Studia Psychologia UKSW, 16(2), 23-42.

SzAFranieC, K. (2014). W oczekiwaniu na bunt młodych. Rocznik Lubuski, 40(2a), 57-71.

SzTompKA, P. (2004). Socjologia. Analiza społeczeństwa. Kraków: Znak. 
Trempata, J., Czyżowka, D. (2002). Rozwój moralny. W: B. Harwas-NapieraŁA, J. TrempaŁA (red.), Psychologia rozwoju człowieka. Rozwój funkcji psychicznych, t. 3 (s. 106-130). Warszawa: PWN.

WrZesień, W. (2011). Dziś prawdziwej młodzieży już nie ma. Ruch Prawniczy, Ekonomiczny i Socjologiczny, 73(2), 359-371.

WrZesień, W. (2017). Współczesne oblicza anomii. Ruch Prawniczy, Ekonomiczny i Socjologiczny, 79(4), 285-304.

\section{AUTONOMIA JAKO ZADANIE (AUTO)EDUKACYJNE MLODZIEŻY}

\section{STRESZCZENIE}

Jedną z konsekwencji życia we współczesnej rzeczywistości, którą można określić mianem ambiwalentnej, heterogenicznej i nieprzewidywalnej, jest szeroko rozumiana indywidualizacja. Przejawia się ona w niemalże wszystkich sferach funkcjonowania jednostki. W wielu ujęciach teoretycznych podmiotowi przypisuje się główną odpowiedzialność za powodzenie życiowe, rozwój kariery czy też kształtowanie tożsamości. Prawidłowość ta skłania do bliższego przyjrzenia się kategorii „,autonomii”. Jej analiza może okazać się szczególnie interesująca w przypadku młodych ludzi, przed którymi stawia się liczne zadania mające prowadzić do osiągnięcia przez nich statusu dorosłości. W niniejszym artykule podjęto próbę uzasadnienia tezy, że autonomia stanowi zadanie (auto)edukacyjne młodzieży, analizowana jako jeden z zasadnych wymiarów podmiotowości człowieka, będący jednocześnie celem rozwoju i naturalną potrzebą okresu adolescencji. W tym kontekście rozpatrywana jest zarówno pod względem wyzwań, jakie jej kształtowanie stawia przed edukacją, jak i pewnych jednostkowych zobowiązań mających znaczenie dla procesu krystalizacji własnego ,ja” młodego człowieka.

Słowa kluczowe: autonomia; młodzież; edukacja; autoedukacja.

\section{AUTONOMY AS A (SELF)EDUCATIONAL TASK OF YOUTH}

\section{SUMMARY}

One of the consequences of living in modern reality, which can be described as ambivalent, heterogeneous and unpredictable - is broadly understood individualization. It manifests itself in almost all spheres of the individual's functioning. In many theoretical approaches, the subject is assigned the main responsibility for life success, career development or identity formation. This regularity prompts a closer look at the category of "autonomy." Her analysis may turn out to be particularly interesting in the case of young people who are faced with numerous tasks to lead them to become adults. This article attempts to justify the thesis that autonomy is the (auto)educational task of young people, analyzed as one of the legitimate dimensions of human subjectivity, which is both the goal of development and the natural need of adolescence. In this context, it is considered both in terms of the challenges its formation poses to education, as well as certain individual commitments relevant to the crystallization process of the young person's self.

Key words: Autonomy; Youth; Education; (Self)education. 